\title{
Effect of Gonadotrophin (Pergonal $®$ ) on Semen Characteristics, Hormonal Profile and Biochemical Constituents of the Seminal Plasma of Mature Ouda Rams
}

\author{
Egu UN* \\ Department of Animal Science and Fisheries, Abia State University, Nigeria
}

Submission: February 06, 2017; Published: June 02, 2017

*Corresponding author: Egu UN, Department of Animal Science and Fisheries, Abia State University, PMB 7010, Umuahia, Nigeria,

Email: ucheegu1@gmail.com

\begin{abstract}
Twelve Ouda rams aged 2-2.6 years and weighed between 40.21-40.32kg were randomly distributed into 3 groups of 4 animals per group with one ram per replicate in a Completely Randomized Design (CRD) and used to determine the effect of Pergonal ${ }^{\circledR}$ on semen characteristics, hormonal profile and biochemical constituents of the seminal plasma. These groups were assigned to 3 levels of Pergonal ${ }^{\circledR}$ injection as treatments. The levels were $0.00 \mathrm{i}$.u (1.00ml physiological saline), 49.50i.u and 99.00i.u Pergonal ${ }^{\circledR}$ represented as $\mathrm{T}_{1}$ (control), $\mathrm{T}_{2}$ and $\mathrm{T}_{3}$ respectively. All the treatments were administered by intramuscular injections. The injections were divided into three doses each and administered intramuscularly in the thigh for three consecutive days. The results of the study showed that Pergonal ${ }^{\circledR}$ enhanced semen quality and was not detrimental to hormonal profile and biochemical constituents of the seminal plasma of the Ouda rams.
\end{abstract}

Keywords: Pergonal ®; Semen quality; Hormones; Seminal plasma constituents; Ouda rams

Abbreviations: FSH: Follicle Stimulating Hormone; LH: Luteinizing Hormone; ANOVA: Analysis of Variance; CRD: Completely Randomized Design

\section{Introduction}

The Ouda sheep is a large long-legged breed with a comvex facial profile found in the Sudan Savannah zone especially in the North Western part of Nigeria. It has a characteristic piecoat colour pattern of an entirely black or brown head and four quarters and white hind quarters. The ears are large, long and droopy. Mature males have horns while females are normally polled (hornless). It has thin tail, the rump is short and extremely sloppy. Mature rams measure $30-60 \mathrm{~kg}$, while the females can weigh $30-45 \mathrm{~kg}$ [1].

The primary aim of induction of spermatogenesis is to improve semen quality $[2,3]$. Spermatogenesis involves the use of follicle stimulating hormone (FSH) and luteinizing hormone (LH). Most of these preparations of FSH and LH are very expensive perhaps because of the brand names, some of them require cold chain storage and often deteriorate because of inadequate storage and handling [4].

There is therefore the need to examine some generic preparations that could induce spermatogenesis in the animals but at the same time are cheap, readily available and easily managed under developing countries conditions. Pergonal ${ }^{\circledR}$, a fertility drug also known as Humagon or Mentrophin is a gonadotrophin preparation lyophilized in vials containing a mixture of gonadotrophins consisting of FSH (DFSH) and LH (DLH) in a ratio 1:1 [5]. Follicle stimulating hormone and LH present in Pergonal ${ }^{\circledR}$ play vital role in the initiation of spermatogenesis.

It has not been determined if the administration of the hormone preparation for spermatogenesis and semen production would induce any side effects on the hormonal profile and seminal plasma constituents of the Ouda rams. This study was therefore carried out to determine the effect of Pergonal ${ }^{\circledR}$ administration on semen quality, hormonal profile and Biochemical constituents of the seminal plasma of Ouda rams.

\section{Materials and Methods}

\section{Experimental animal and their management}

Twelve healthy, sexually matured Ouda rams aged 2-2.6 years were used for this study. The animals were purchased from 
the local markets and housed in clean pens constructed in such a way that the rams could come outside during the day for access to sunlight and forage. The animals were dewormed two times within the experimental period. The actual experimental period lasted for complete 70 days. Routine inspection for cleanliness was carried out. Freshly cut forages consisting of Panicum maximum, Aspilia africana, Pennisetum purpureun (Elephant grass) were fed as basal diet and a concentrate ration of Grower Mash was used as supplement. The animals were fed twice daily (in the morning and evening). Salt lick was provided as mineral supplement. Water was given ad libitum to the animals.

\section{Experiment design and drug administration}

The twelve Ouda rams were divided into 3 experimental groups consisting of 4 animals per group with one ram per replicate in a Completely Randomized Design (CRD). These groups were assigned to 3 levels of Pergonal ${ }^{\circledR}$ as treatments. The levels of Pergonal ${ }^{\circledR}$ were 0.00i.u, 49.50i.u and 99.00i.u represented as $\mathrm{T}_{1}, \mathrm{~T}_{2}$, and $\mathrm{T} 3$ respectively. $\mathrm{T}_{1}$, which contained no Pergonal@ served as the control. The rams were treated by intramuscular injections.

The injections were given as follows:

Pergonal was supplied in 5 vials, each vial containing FSH 75i.u and LH 75i.u. The content of the first vial was dissolved in $1 \mathrm{ml}$ of physiological saline solution immediately prior to use, resulting in a solution of PFSH 75i.u plus PLH 75i.u per ml.

All treatments were administered intramuscularly on the hind leg (thigh) of each ram using a one $\mathrm{ml}$ syringe with $0.01 \mathrm{ml}$ graduation.

\section{Semen collection and evaluation}

Semen collection was done by electro-ejaculation method [6] after one week of Pergonal ${ }^{\circledR}$ administration and continued at 2 weeks interval for 9 weeks. The semen was collected between $8.00 \mathrm{am}$ and $9.00 \mathrm{am}$. This was to ensure that quality semen would be obtained. A transparent graduated tube immersed in a protective jacket containing water at $37^{\circ} \mathrm{C}$, with a funnel was used to collect the semen. The animal's hind limbs were held up by an assistant, with shoulder and fore limbs of the animal held tightly between the two legs of the assistant. The Vaseline lubricated probe was inserted gently into the rectum. The rhythmic stimulation of the ampullae and sacral nerve plexus caused erection and subsequently ejaculation within few minutes.

Semen evaluation was done as promptly as possible post collection as described by [7] for qualitative and quantitative parameters such as semen volume, semen $\mathrm{pH}$, sperm concentration, sperm motility, live sperm percentage, dead sperm percentage.

\section{Hormonal assay}

Blood sample $(5 \mathrm{ml}$ each) were obtained with needle and syringe by jugular vein puncture of the twelve rams on day 7 after the Pergonal ${ }^{\circledR}$ injection for testosterone, FSH and LH evaluation. It was cooled immediately in iced water and transferred to the laboratory, refrigerated at $4{ }^{\circ} \mathrm{C}$ for 1 hour and the serum separated by centrifugation at $5,000 \mathrm{rpm}$ for 10 minutes. The serum was stored immediately at $-20{ }^{\circ} \mathrm{C}$ until enzyme immune assayed (EIA) for testosterone, FSH and LH as described by [8].

\section{Biochemical constituents of seminal plasma}

Semen samples used for estimation of biochemical constituents of seminal plasma were centrifuged at $15,000 \mathrm{rpm}$ for 15 minutes. The seminal plasma samples were immediately subjected to laboratory analysis for the following biochemical parameters: urea, glycerophos-phocholine, ascorbic acid, sodium, potassium, bicarbonate and fructose (Table $1 \& 2$ ).

Table 1: Doses of Pergonal ${ }^{\circledR}$ Administered to mature Ouda Rams.

\begin{tabular}{|c|c|c|c|}
\hline \multicolumn{4}{|c|}{ Treatment Dosage (ml) } \\
\hline Day & T1 & T2 & T3 \\
\hline 1 & 0 & 0.11 & 0.22 \\
\hline 2 & 0 & 0.11 & 0.22 \\
\hline 3 & 0 & 0.11 & 0.22 \\
\hline Total & 0 & 0.33 & 0.66 \\
\hline
\end{tabular}

Table 2: Concentration of Pergonal ${ }^{\circledR}$ on Mature Ouda Rams.

\begin{tabular}{|c|c|c|c|}
\hline \multicolumn{4}{|c|}{ Concentration Of Personal® (i.u) } \\
\hline Day & T1 & T2 & T3 \\
\hline 1 & 0 & 16.5 & 33 \\
\hline 2 & 0 & 16.5 & 33 \\
\hline 3 & 0 & 16.5 & 33 \\
\hline Total & 0 & 49.5 & 99 \\
\hline
\end{tabular}

Sodium and potassium concentrations were estimated with a flame photometer on samples suitably diluted with deionized water, while bicarbonate and urea concentrations were determined according to the method of [9]. Fructose concentration in the plasma was determined according to the procedure of [10]. Glycerophosphocholine and ascorbic acid concentrations were determined according to the method [11].

\section{Data analysis}

Data collected on semen characteristics, hormonal profile and seminal plasma constituents of Ouda rams were subjected to analysis of Variance (ANOVA) using the technique of [12] Significant treatment means were separated using Duncan's New Multiple Range Test as described by [13].

\section{Results and Discussion}

The results of Pergonal $^{\circledR}$ administration on semen characteristics of Ouda rams are shown in (Table 3). There were significant difference $(\mathrm{P}<0.05)$ among the treatment groups in semen volume. Rams on $\mathrm{T}_{3}$ recorded the highest value of $1.12 \mathrm{ml}$ in semen volume and this was significantly different $(\mathrm{P}<0.05)$ from rams on $\mathrm{T}_{2}$ which were similar $(\mathrm{P}>0.05)$ to rams on $\mathrm{T} 1$ in semen volume. There was no significant difference $(\mathrm{P}>0.05)$ between rams on $\mathrm{T}_{3}$ and $\mathrm{T}_{1}$ in semen volume. The highest 
semen volume obtained on this study $(1.12 \mathrm{ml})$ was lower than the mean ejaculate volume of $1.25+0.7 \mathrm{ml}$ reported by [14] in Yankasa rams of similar ages [15] noted that methods of semen collection, season of the year, breed, age, body weight of animal, scrotal circumference and frequency of semen harvest can affect ejaculate volume in rams.

Table 3: Effect of Pergonal ${ }^{\circledR}$ on Semen Characteristics of Mature Ouda Rams.Means within row having different superscript are significantly $(P<0.05)$ different. SEM=Standard error of means.

\begin{tabular}{|c|c|c|c|c|}
\hline \multicolumn{5}{|c|}{ Treatment (Pergonal ${ }^{\circledR}$ i.u) } \\
\hline Parameters & $\mathrm{T}_{1} 0.00$ & $\mathrm{~T}_{2} 49.50$ & $\mathrm{~T}_{3} 99.00$ & SEM \\
\hline Volume(ml) & $1.00^{\mathrm{ab}}$ & $0.84^{\mathrm{b}}$ & $1.12^{\mathrm{a}}$ & 0.36 \\
\hline Mass motility & $4.30^{\mathrm{b}}$ & $4.55^{\mathrm{a}}$ & $4.55^{\mathrm{a}}$ & 0.08 \\
\hline Individual motility (\%) & $75.60^{\mathrm{b}}$ & $77.50 \mathrm{a}^{\mathrm{b}}$ & $80.20^{\mathrm{a}}$ & 1.33 \\
\hline $\mathrm{pH}$ & 7.8 & 8 & 8 & 0.07 \\
\hline $\begin{array}{c}\text { Sperm concentration } \\
\text { (x106/ml) }\end{array}$ & $0.48^{\mathrm{b}}$ & $0.68^{\mathrm{ab}}$ & $0.85^{\mathrm{a}}$ & 0.11 \\
\hline $\begin{array}{c}\text { Proportion of live sperm } \\
\text { cells (\%) }\end{array}$ & $75.00^{\mathrm{b}}$ & $79.00^{\mathrm{ab}}$ & $86.00 \mathrm{a}$ & 3.21 \\
\hline $\begin{array}{c}\text { Proportion of normal } \\
\text { sperm cells (\%) }\end{array}$ & $85.00^{\mathrm{b}}$ & $89.00^{\mathrm{ab}}$ & $90.00^{\mathrm{a}}$ & 1.53 \\
\hline $\begin{array}{c}\text { Proportion of dead sperm } \\
\text { cells (\%) }\end{array}$ & $25.00^{\mathrm{a}}$ & $21.00^{\mathrm{ab}}$ & $14.00^{\mathrm{b}}$ & 3.21 \\
\hline
\end{tabular}

There were significant difference $(\mathrm{P}<0.05)$ among the treatment groups in mass motility. Rams on $\mathrm{T}_{2}$ and $\mathrm{T}_{3}$ recorded the highest value of 4.55 in mass motility and this differed significantly $(\mathrm{P}<0.05)$ from rams on $\mathrm{T} 1$ which had the lowest value of 4.50 in mass motility. Mass motility ranges from 1 to 5 [16]. There were significant difference $(\mathrm{P}<0.05)$ among the treatment groups in individual motility. Rams on $\mathrm{T}_{3}$ recorded the highest score of $80.20 \%$ in individual motility and this differed significantly $(\mathrm{P}<0.05)$ from rams on $\mathrm{T}_{1}$ which were similar $(\mathrm{P}>0.05)$ to rams on $\mathrm{T}_{2}$ in individual motility. There was no significant different $(\mathrm{P}>0.05)$ between rams on $\mathrm{T}_{3}$ and $\mathrm{T}_{2}$ in individual motility. The lowest score of $75.60 \%$ in individual motility was observed in rams on $\mathrm{T}_{1}$. The highest score in individual motility obtained in this study (80.20\%) was lower than the score of $85.0+7.5 \%$ reported by in Yankasa rams of similar ages. Sperm motility is affected by frequency of semen collection.

There were no significant differences $(\mathrm{P}>0.05)$ among the treatment groups in semen $\mathrm{pH}$. Rams on $\mathrm{T}_{2}$ and $\mathrm{T}_{3}$ recorded the highest numerical value of 8.00 in semen $\mathrm{PH}$. The lowest numerical value in semen $\mathrm{pH}$ was observed in rams on $\mathrm{T}_{1}$ (7.80). Semen $\mathrm{pH}$ values obtained in this study were within the normal range of 7-8 reported by [17]. The measured $\mathrm{pH}$ depends on the length of time since ejaculation and it tends to increase shortly after ejaculation as a result of loss of $\mathrm{CO}_{2}$.

There were significant difference $(\mathrm{P}<0.05)$ among the treatment groups in sperm concentration. Rams on $\mathrm{T}_{3}$ recorded the highest value of $0.85(\mathrm{x} 106 / \mathrm{ml})$ in sperm concentration and this differed significantly $(\mathrm{P}<0.05)$ from rams on $\mathrm{T}_{1}$ which were similar $(\mathrm{P}>0.05)$ to rams on $\mathrm{T}_{2}$. There was no significant difference $(\mathrm{P}>0.05)$ between rams on $\mathrm{T}_{3}$ and $\mathrm{T}_{2}$ in sperm concentration. The highest sperm concentration value of $0.85 \mathrm{R}(\mathrm{x} 106 / \mathrm{ml})$ obtained in this study was within the highest value of $0.79+0.07(\mathrm{x} 106 / \mathrm{ml})$ for sperm concentration reported by in Yankasa rams of similar ages. This was also within the normal range of 200 to more than 1,000 million $\mathrm{spz} / \mathrm{ml}$ reported by [18]. Normally an increase in the semen collection frequency is associated with a decrease in sperm concentration $[19,20]$.

There were significant difference $(\mathrm{P}<0.05)$ among the treatment groups in percentage live sperm cells. Rams on $\mathrm{T}_{3}$ recorded the highest percentage of live sperm cells $(86.00 \%)$ and this differed significantly $(\mathrm{P}<0.05)$ from rams on $\mathrm{T}_{1}$ which were similar $(\mathrm{P}>0.05)$ to rams on $\mathrm{T} 2$ in percentage of live sperm cells. There was no significant difference $(P>0.05)$ between rams on $\mathrm{T}_{3}$ and $\mathrm{T}_{2}$ in percentage of live sperm cells. The percentages of live sperm cells obtained in this study were lower than the range of $77.2+9.7-79.4+4.9 \%$ reported in Nigerian Yankasa rams, except rams on $\mathrm{T}_{3}$ whose percentage live sperm cells was within the range.

There were significant difference $(\mathrm{P}<0.05)$ among the treatment groups in normal sperm cells. Rams on $\mathrm{T} 3$ recorded the highest percentage of normal sperm cells $(90.00 \%)$ and this differed significantly $(\mathrm{P}<0.05)$ from rams on $\mathrm{T}_{1}$ which were similar $(\mathrm{P}>0.05)$ to rams on $\mathrm{T}_{2}$ in percentage of normal sperm cells. There was no significant difference $(\mathrm{P}>0.05)$ between rams on $T_{3}$ and $T_{2}$ in percentage of normal sperm cells. The percentages of normal sperm cells obtained in this study were within the range of $82.4+3.8-87.0+8.2 \%$ reported in Nigerian Yankasa rams.

There were significant difference $(\mathrm{P}<0.05)$ among the treatment groups in dead sperm cells. Rams on $\mathrm{T}_{1}$ recorded the highest percentage of dead sperm cells $(25.00 \%)$ and this differed significantly $(\mathrm{P}<0.05)$ from rams on $\mathrm{T}_{3}$ which were similar $(\mathrm{P}>0.05)$ to rams on $\mathrm{T} 2$ in percentage of dead sperm cells. There was no significant difference $(\mathrm{P}>0.05)$ between rams on $\mathrm{T}_{1}$ and $\mathrm{T}_{2}$ in percentage of dead sperm cells. The lowest percentage of dead sperm cells was observed in rams on $\mathrm{T}_{3}(14.00 \%)$.

The observation in this study that the group that received higher $(0.66 \mathrm{ml})$ dose of the test drug recorded the highest percentage of live sperm cell, normal sperm cells and lowest percentage of dead sperm cells suggest that a high dose of the drug such as $0.66 \mathrm{ml} / \mathrm{ram}$ within 3 days given in this study could have high capacity for induction of spermatogenesis, improvement of semen quality and have no deleterious effects on sperm cells.

The result of Pergonal administration on hormonal profile of Ouda rams are shown in (Table 4). There were significant differences $(\mathrm{P}<0.05)$ among the treatment groups in follicle stimulating hormone (FSH). Rams on $\mathrm{T}_{2}$ recorded the highest value of 11.80i.u/L in FSH and this differed significantly $(\mathrm{P}<0.05)$ from rams on $\mathrm{T}_{3}$ which were similar $(\mathrm{P}>0.05)$ to rams 
on T1 in FSH values. There was no significant difference $(\mathrm{P}>0.05)$ between rams on $\mathrm{T}_{2}$ and $\mathrm{T}_{1}$ in FSH values. The lowest value in FSH was observed in rams on $\mathrm{T}_{3}(10.75 \mathrm{i}$.u/L). The observation in this study that the FSH value in the rams treated with $0.33 \mathrm{ml}$ Pergonal was higher than in the group that received higher dose of the drug suggest that a high dose of the drug such as $0.66 \mathrm{ml} /$ ram with 3 days given in this study could excite suppressive effect on the hypothalamus.

Table 4: Effect of Pergonal ${ }^{\circledR}$ on Hormonal Profile of Mature Ouda Rams. Means within row having different superscript are significantly $(P<0.05)$ different. SEM=Standard error of means.

\begin{tabular}{|c|c|c|c|c|}
\hline Parameters & $\mathbf{T}_{\mathbf{1}} \mathbf{0 . 0 0}$ & $\mathbf{T}_{\mathbf{2}} \mathbf{4 9 . 5 0}$ & $\mathbf{T}_{\mathbf{3}} \mathbf{9 9 . 0 0}$ & $\mathbf{S E M}$ \\
\hline FSH (i.u/L) & $11.75^{\mathrm{ab}}$ & $11.80^{\mathrm{a}}$ & $10.75^{\mathrm{b}}$ & 0.34 \\
\hline LH (i.u/L) & $5.86^{\mathrm{a}}$ & $5.70^{\mathrm{ab}}$ & $5.40^{\mathrm{b}}$ & 0.13 \\
\hline $\begin{array}{c}\text { Testosterone } \\
(\mathrm{ng} / \mathrm{ml})\end{array}$ & $18.30^{\mathrm{ab}}$ & $18.50^{\mathrm{a}}$ & $17.40^{\mathrm{b}}$ & 0.34 \\
\hline
\end{tabular}

There were significant differences $(\mathrm{P}<0.05)$ among the treatment groups in luteinizing hormone $(\mathrm{LH})$. Rams on $\mathrm{T}_{1}$ recorded the highest value of 5.86(i.u/L) in LH and this differed significantly $(\mathrm{P}<0.05)$ from rams on $\mathrm{T}_{3}$ which were similar $(\mathrm{P}>0.05)$ to rams on $\mathrm{T}_{2}$ in $\mathrm{LH}$ values. There was no significant difference $(\mathrm{P}>0.05)$ between rams on $\mathrm{T} 1$ and $\mathrm{T}_{2}$ in $\mathrm{LH}$ values. The lowest value in $\mathrm{LH}$ was observed in rams on $\mathrm{T}_{3}(5.40 \mathrm{i}$.u/L). The observation in this study that the LH value in rams on the control treatment $\left(\mathrm{T}_{1}\right)$ was higher $(\mathrm{P}<0.05)$ than in the group that received higher dose of Pergonal ${ }^{\circledR}$ suggest that the higher dose of the drug given in this study $0.66 \mathrm{ml} / \mathrm{ram}$ within 3 days could excite suppressive effect on the hypothalamus. It is common knowledge that $\mathrm{LH}$ as interstitial cell stimulating hormone (ICSH) stimulates the interstitial cells of leg dig to produce testosterone which facilitates the process of spermatogenesis.

There were significant differences $(\mathrm{P}<0.05)$ among the treatment groups in serum testosterone. Rams on $\mathrm{T}_{2}$ recorded the highest value of $18.50 \mathrm{ng} / \mathrm{ml}$ in testosterone and this differed significantly $(\mathrm{P}<0.05)$ from rams on $\mathrm{T}_{3}$ which were similar $(\mathrm{P}>0.05)$ to rams on $\mathrm{T}_{1}$ in testosterone values. There was no significant difference $(\mathrm{P}>0.05)$ between rams on $\mathrm{T}_{2}$ and $\mathrm{T} 1$ in testosterone values. The testosterone values obtained in this study were within the normal range of $0-20 \mathrm{ng} / \mathrm{ml}$ reported in Sheep [21].

The results of Pergonal administration on biochemical constituents of the seminal plasma of Ouda rams are shown in (Table 5) There were significant differences $(\mathrm{P}<0.05)$ among the treatment groups in seminal plasma urea. Rams on $\mathrm{T}_{1}$ recorded the highest value of $44.80(\mathrm{mg} / 100 \mathrm{ml})$ in seminal plasma urea and this differed significantly $(\mathrm{P}<0.05)$ from rams on $\mathrm{T}_{3}$ which were similar $(\mathrm{P}>0.05)$ to rams on $\mathrm{T}_{2}$ in urea level in the seminal plasma. There was no significant rams on $\mathrm{T}_{1}$ and $\mathrm{T}_{2}$ in urea level in the seminal plasma. The values for urea in seminal plasma obtained in the Pergonal treated group were lower than the normal range of $43-75(\mathrm{mg} / 100 \mathrm{ml})$ reported [22] in rams. However, the values for urea in this study were within the range of $17-42 \mathrm{mg} / \mathrm{dl}$ reported by $[23,24]$ reported that sharp increase in plasma urea level could result in gonadal degeneration and infertility with reduced sperm production and loss of libido.

Table 5: Effect of Pergonal ${ }^{\circledR}$ on Biochemical Constituents of Seminal Plasma of mature Ouda Rams .Means within row having different superscript are significantly $(P<0.05)$ different. SEM=Standard error of means.

\begin{tabular}{|c|c|c|c|c|}
\hline Parameters & $\mathbf{T}_{\mathbf{1}} \mathbf{0 . 0 0}$ & $\mathbf{T}_{\mathbf{2}} \mathbf{4 9 . 5 0}$ & $\mathbf{T}_{\mathbf{3}} \mathbf{9 9 . 0 0}$ & $\mathbf{S E M}$ \\
\hline Urea (mg/100ml) & $44.80^{\mathrm{a}}$ & $42.30^{\mathrm{ab}}$ & $41.50^{\mathrm{b}}$ & 0.98 \\
\hline $\begin{array}{c}\text { Ascorbic acid } \\
(\mathrm{mg} / 10 \mathrm{ml})\end{array}$ & $5.70^{\mathrm{b}}$ & $6.80^{\mathrm{ab}}$ & $7.60^{\mathrm{a}}$ & 0.55 \\
\hline $\begin{array}{c}\text { Citric acid } \\
(\mathrm{mg} / 100 \mathrm{ml})\end{array}$ & $123.00^{\mathrm{b}}$ & $134.00^{\mathrm{ab}}$ & $137.00^{\mathrm{a}}$ & 4.26 \\
\hline Sodium (mmol/L) & 45.6 & 46.7 & 46.8 & 0.41 \\
\hline Potassium(mmol/L) & $4.50^{\mathrm{b}}$ & $5.90^{\mathrm{a}}$ & $5.80^{\mathrm{ab}}$ & 0.45 \\
\hline $\begin{array}{c}\text { Bicarbonate } \\
(\mathrm{mmol} / \mathrm{L})\end{array}$ & $23.00^{\mathrm{b}}$ & $25.25^{\mathrm{ab}}$ & $26.00^{\mathrm{a}}$ & 0.91 \\
\hline Fructose (mmol/L) & $255.00^{\mathrm{a}}$ & $247.00^{\mathrm{b}}$ & $250.00^{\mathrm{ab}}$ & 1.86 \\
\hline
\end{tabular}

There were significant differences $(\mathrm{P}<0.05)$ among the treatment groups in ascorbic acid level. Rams on $\mathrm{T}_{3}$ recorded the highest value of $7.60(\mathrm{mg} / 100 \mathrm{ml})$ in ascorbic acid in the seminal plasma and this differed significantly $(\mathrm{P}<0.05)$ from rams on $\mathrm{T}_{1}$ which were similar $(P>0.05)$ to rams on $T_{2}$ in ascobic acid level in the seminal plasma. There was no significant difference $(\mathrm{P}>0.05)$ between rams on $\mathrm{T}_{3}$ and $\mathrm{T}_{2}$ in Ascorbic acid level in the seminal plasma. The lowest value in Ascorbic acid was observed in rams on $\mathrm{T}_{1}(5.70 \mathrm{mg} / 100 \mathrm{ml})$. Studies have shown that vitamin $\mathrm{C}$ plays a vital role in enhancing sperm motility, keeping sperm strong by protecting them from free radicals [25].

There were significant differences $(\mathrm{P}<0.05)$ among the treatment groups in citric acid level in the seminal plasma. Rams on $\mathrm{T}_{3}$ recorded the highest value of $137(\mathrm{mg} / 100 \mathrm{ml})$ and this different significantly $(\mathrm{P}<0.05)$ from rams on $\mathrm{T}_{1}$ which were similar $(\mathrm{P}>0.05)$ to rams on $\mathrm{T}_{2}$ in citric acid level in the seminal plasma. There was no significant difference $(\mathrm{P}>0.050$ between rams on $\mathrm{T}_{3}$ and $\mathrm{T}_{2}$ in citric acid levels in the seminal plasma. The lowest level of citric acid in the seminal plasma was observed in rams on $\mathrm{T}_{1}(123.00 \mathrm{mg} / 100 \mathrm{ml})$. Citric acid and Ascorbic acid are known to have very similar properties [26].

There were no significant differences $(\mathrm{P}<0.05)$ among the treatment groups in seminal plasma sodium. Rams on $\mathrm{T}_{3}$ recorded the highest numerical value of $46.80(\mathrm{mmol} / \mathrm{L})$ in seminal plasma sodium. The lowest numerical value in seminal plasma sodium was observed in rams on $\mathrm{T}_{1}(45.60(\mathrm{mmol} / \mathrm{L})$. Sodium bicarbonate in seminal plasma stimulates sperm motility [27].

There were significant differences $(\mathrm{P}<0.05)$ among the treatment groups in seminal plasma potassium. Rams on $\mathrm{T}_{2}$ recorded the highest value of $5.90(\mathrm{mmol} / \mathrm{L})$ in seminal plasma potassium and this differed significantly $(\mathrm{P}<0.05)$ from rams on $\mathrm{T}_{1}$ which were similar $(\mathrm{P}>0.05)$ to rams on $\mathrm{T}_{3}$ in potassium values. There was no significant difference $(\mathrm{P}>0.05)$ between rams on $\mathrm{T}_{2}$ and $\mathrm{T}_{3}$ in seminal plasma potassium values. Potassium is known to maintain sodium levels and facilitate blood circulation and flow [28]. 
There were significant differences $(\mathrm{P}<0.05)$ among the treatment groups in seminal plasma bicarbonate. Rams on $\mathrm{T}_{3}$ recorded the highest value of $26.20(\mathrm{mmol} / \mathrm{L})$ in seminal plasma bicarbonate and this differed significantly $(\mathrm{P}<0.05)$ from rams on $\mathrm{T}_{1}$ which were similar $(\mathrm{P}>0.05)$ to rams on $\mathrm{T}_{2}$ in bicarbonate values. There was no significant difference $(P>0.05)$ between rams on $\mathrm{T} 3$ and $\mathrm{T}_{2}$ in bicarbonate values. The bicarbonate values obtained in this study were higher than the mean value of $20.00(\mathrm{mmol} / \mathrm{L})$ reported who also inferred that sodium bicarbonate in seminal plasma stimulates sperm motility.

There were significant differences $(\mathrm{P}<0.05)$ among the treatment groups in seminal plasma fructose. Rams on $\mathrm{T}_{1}$ recorded the highest value of $255.00(\mathrm{mmol} / \mathrm{L})$ in seminal plasma fructose and this differed significantly $(\mathrm{P}<0.05)$ from rams on $\mathrm{T}_{2}$ which were similar $(\mathrm{P}>0.05)$ to rams on $\mathrm{T}_{3}$ in fructose values. There was no significant difference $(\mathrm{P}>0.05)$ between rams on $\mathrm{T}_{1}$ and $\mathrm{T}_{3}$ in seminal plasma fructose values are reported that fructose level is a measure of seminal vesicle function being a source of energy for the sperm. Fructose values obtained in this study were within the range of $136-628(\mathrm{mg} / 100 \mathrm{ml})$ for seminal plasma fructose reported by [29].

\section{Conclusion}

The results of this study showed that Pergonal ${ }^{\circledR}$ improved semen quality and biochemical constituents of seminal plasma at the level of 99.00i.u without any deleterious effects on hormonal profile. Though the hormonal levels fall within the normal ranges for adult sheep, the variations observed suggest the need to constantly monitor hormonal profile of Ouda rams under Pergonal $®$ treatment.

\section{References}

1. Oni OO (2002) Breeds and Genetic Improvement of small ruminant in: Manual for small ruminant Production in Nigeria: A training workshop on small ruminant production held at the National Animal Production Research Institute Zaria Nigeria. 13(18): 1-7.

2. Ameh M (2004) Effect of Pergonal ${ }^{\circledR}$ on semen quality, haematological values and carcass characteristics of the Nigerian Local cocks. MSc Thesis Department of Animal Science and Fisheries Abia State University, Umuahia, Nigeria.

3. Abu AH Ameh, Iheukwumere FC (2006) Semen quality of Nigerian Local cocks treated with human menopausal gonadotrophin $\left(\right.$ Pergonal ${ }^{\circledR}$ ). Livestock Research for Rural Development 18(3).

4. Herbert U, Okoro P, Umesiobi Do, Iloeje MU (2000) Effects of two preparations of clomiphene citrate on the superovulation of West African Dwarf Ewes. 14 ${ }^{\text {th }}$ Int Congr On Anim Reprod Sweden 2: 114.

5. Dixon TA, Hopkins GJ (1996) Super ovulation in cattle using porcine pituitary Gonadotrophin preparation (PhissetSerono) Plusset Scientic Literature Serono Veterinary, Bome Italy. pp. 22-23.

6. Noakes DE, Parkinsom TJ and Gary CW (2001) Veterinary Reproduction and Obstetrics England $8^{\text {th }}$ Edition.

7. Rodriguez-Martinez H, Barth AD (2007) In vitro Evaluation of sperm quality related toan invivo function and fertility. inIn: Juengel JJ, Murray JE, Smith Mi (Eds.), Reproduction in Domestic Animals VI. Notthingham University press, Notthngham, UK, 39-54.
8. Micallef IA, Hays MM, Latif A, Alhasan R, Sufi SB (1995) Serum binding of steroid Tracer's and its possible effects on Direct steroid immune assay. Ann Clin Biochem 32(6): 566-574.

9. Baker FJ, Silverton RE (1986) Introduction to Medical Laboratory Technology. (6 ${ }^{\text {th }}$ edn), Butter-Worth England.

10. Singgh SP (2004) Practical Manual in Biochemistry. In: Jain SK (Edn.), ( $5^{\text {th }}$ edn), India, pp. 203-255.

11. Robert KM, Daryl KG, Peter AM, Victor WR (2000) Mayers Biochemistry. ( $25^{\text {th }}$ edn), McGraw Hill, New York, USA, pp. 763-765.

12. Steel RGD, Torrie JH (1980) Principles and procedures of Statistics. A Biometrical Approach. ( $2^{\text {nd }}$ edn), Mc. Graw-Hill Book, Co. Inc., New York, USA, 12(5): 441.

13. Obi IU (1990) Statistical methods of detecting differences between treatment means. ( $2^{\text {nd }}$ edn), Enugu, Snap press, Nigeria. 24-35.

14. Iheukwumere FC, Herbert U, Umesiobi DO (2001) Biochemical Evaluation of seminal plasma in Yankasa Rams under different Intensities of Semen Collection. Int J Agric Rural Dev 2: 29-34.

15. Iheukwumere FC, Abu AH, Ndubuisi EC (2008) Effect of FSH+LH $\left(\right.$ Pergonal $^{\circledR}{ }^{\circledR}$ Treatment and Serum Metabolites of West African Dwarf Goats. Journal of Animal and Veterinary Advances 7(1): 46-50.

16. Bracket BG (2005) Physiology of Domestic Animals Twelfth Edition. In Reece WO (Ed.), pp. 670-691.

17. Meacham R (2002) Perspectives and Editorials. Andrologia JA Androl 23: 330-331.

18. Rodriguez-Martinez H (2003) Laboratory Semen Assessment and Prediction of Fertility; Still Utopia? Reprod Domest Anim 38(4): 312318.

19. Aroita Z, Faketo MV, Martin-Rill-0 S, Dealba C, Moreno C, et al. (2000) Effect of collection frequency on production, quality and storage of Young Bucks Semen. $7^{\text {th }}$ World Rabbi Congress, Valencia, Volume A.

20. Iheukwumere FC, Okereke C (1990) Effect of frequent ejaculation on semen characteristics of Nigerian Yankasa Rams. Small Ruminant Research 3(1): 77-83.

21. King GI, Nelmann-Sorenson A, Tribe DE (1993) Reproduction in Domesticated Animals. ( $9^{\text {th }}$ Edn) World Animal Science B. Disciplinary Approach. Elsevier science Publishers, London New York, USA, p. 106.

22. Roller MM, Riedmann GS, Romkema GE, Swanson RN (1982) Ovine Blood Chemistry values measured during Ammonia toxicosis. Am J Vet Res 43(6): 1068 -1071.

23. Kaneko JJ, Harvey JW, Bruss MI (1997) Clinical Biochemistry of Domestic Animals. ( $5^{\text {th }}$ edn), Academic Press, San Diego Carliffonia, USA, pp. 885-905.

24. Cortada CNM, Lucci CO, Gonazalez RAF, Valentin R, de mattos CB (2000) Plasma Urea levels on Reproductive Parameters of wool-less Rams (Ovisaries, linnaeus, 1758). Brazilian Journal of Veterinary Research and Animal Science 37(6).

25. Anonymous (2013) www.malefertilitysupplements.com.

26. Strzeszewski K (2010) www.differencebetweencitricacidandascobicacid. org.

27. Anonymous (2013) www.howtoincreasespermcount.org.

28. Okamura NS, Tajima Y, Soejimaj A, Masudap H, Sugita Y (2006) Sodium Bicarbonate in seminal plasma stimulates the motility of Mammalian spermatozoa through Direct Activation of Adenylate cyclase. J Biol Chem: 9699-9705.

29. Gonzles GF, Kortebani F, Mazzolli AB (1993) Hyperviscosity and hypofunction of the seminal vesicles Arch Androl 30(1): 63-68. 
This work is licensed under Creative Commons Attribution 4.0 Licens

DOI: 10.19080/JDVS.2017.02.555598
Your next submission with Juniper Publishers will reach you the below assets

- Quality Editorial service

- Swift Peer Review

- Reprints availability

- E-prints Service

- Manuscript Podcast for convenient understanding

- Global attainment for your research

- Manuscript accessibility in different formats

( Pdf, E-pub, Full Text, Audio)

- Unceasing customer service

Track the below URL for one-step submission https://juniperpublishers.com/online-submission.php 